\title{
THE HISTORICAL AND PEDAGOGICAL ANALYSIS OF THE CATEGORY "EDUCATION"
}

\section{ІСТОРИКО-ПЕДАГОГІЧНИЙ АНАЛІЗ КАТЕГОРІї “ОСВІТА”}

\author{
YULIIA BABAIAN, \\ Candidate of Psychological \\ Sciences, Associate Professor \\ ЮЛІЯ БАБАЯН, \\ кандидат психологічних наук, доцент \\ https://orcid.org/0000-0002-2136-7982 \\ $\begin{gathered}\text { Mykolaiv V.O. Sukhomlynsky } \\ \text { National University }\end{gathered}$
Миколаївський національний
університет імені \\ В.О. Сухомлинського \\ 24 Nicholskaya St. \\ Mykolaiv (Ukraine), 54030 \\ $\triangle$ вул. Нікольська, 24 \\ м. Миколаїв, Украӥна, 54030
}

Original manuscript received July 17, 2019

Revised manuscript accepted September 12, 2019

\begin{abstract}
The article presents a retrospective analysis of the concept of "education", which appeared in the scientific and pedagogical literature at the end of the eighteenth century as a synonym for the word "upbringing" and gradually acquired a wider context. Such methods used to for writing the article: analysis of literary sources, systematization and generalization of data to identify the state of the survey problem, the method of scientific abstraction.

Using the above methods, it is determined that the dynamics of changes in the interpretation of the definition of "education", the diversity of its context is due to the increasing role of the educational sphere for the life and development of modern society. Today, there are different approaches to the interpretation of this concept, which are considered and summarized in this article: education as a characteristic of ethnicity, civilization, society; education as a socio-cultural phenomenon, as a special sphere of social life; education as a value (personal, social, state); education as a system of (various general education (state and non-state) institutions and educational institutions); education as a process (holistic unity of learning, education, development, self-development of personality); education as a tiered result.

Characteristics, signs and tendencies of development of education at the present stage are analyzed. The progress of mankind, the development of society, the national security of states today are determined precisely by the development of the educational sphere. Human resources, personal capital become the lever, the dimension on which the competitiveness of any state depends.

The functions of education are revealed, among which the following can be
\end{abstract}


distinguished: human creation - promoting the formation of a certain level of knowledge, literacy, education; technological - formation of skills and abilities in different types of activity; humanistic - the formation in the growing personality of high morality, culture, spiritual values. Effective components of education are identified: literacy; intelligence; professional competence; culture; mentality. The path from literacy to mentality is the process of moving the individual from the educational minimum to the highest educational outcomes. intelligence

Keywords: education, system of education, training, upbringing, value, culture,

Вступ. Прискорені темпи соціально-економічного розвитку, процеси глобалізації та світової інтеграції, кардинальні цивілізаційні трансформації на початку XXI століття викликають зміни в усіх сорерах суспільного життя.

Освіта в її соціальному розумінні $€$ визначальним елементом процесу життєдіяльності суспільства, від якого залежить його нормальний стабільний розвиток і майбутнє. Система освіти віддзеркалює проблеми і потреби суспільства в певний історичний період, виконуючи направляючу, стабілізуючу та поступальну функції прогресу в плані всебічного розвитку культури, гармонійної зміни поколінь й інтелектуального розвитку особистості.

В умовах глобальних викликів поступово переосмислюється роль освіти в забезпеченні економічного розвитку. У сучасній світовій економіці наука й освіта займають одне з провідних місць, є одними з головних її структурних чинників. Саме тому розвинуті держави світу наголошують освіту визначальною стратегічною галуззю інтелектуального, духовного, соціального й економічного розвитку.

На думку Т. Яровенко, “освіта перестає бути видом невиробничого споживання, а стає інвестицією в людський капітал, що приносить економічні (збільшення ВВП) та соціальні (зниження безробіття, бідності, злочинності, тощо) вигоди. Таким чином, підвищення освітнього рівня впливає на економічне зростання, а розвиток освіти стає основою прогресу суспільства" (Яровенко, 2015: 168).

Освіта в сучасному світі, за словами О. Уваркіної, "не може існувати поза процесами постійної модернізації і трансформації, адже саме освітнє середовище є провісником ключових соціальних змін, які динамічно відбуваються в рамках інформаційної цивілізації, що постійно прагне до цивілізації знання і гуманізму" (Уваркіна, 2012: 38).

Водночас цілком зрозумілим $€$ те, що на першому плані мають стояти питання ефективності тих трансформаційних процесів, що відбуваються в освітянській сфері.

Зазначені проблеми особливо актуальними є для нашої країни, де в умовах глибоких змін політичного та соціально-економічного характеру й одночасного переходу до постіндустріального й інформаційного суспільства відбуваються докорінні зміни у сфері освіти, зростає ії суспільна значимість і цінність (Огнев'юк, 2003).

Ці обставини зумовлюють пошук нових шляхів вдосконалення 
системи освіти, покликаної забезпечити подальше підвищення інтелектуального, культурного і духовно-морального потенціалу нації, інтеграцію у світовий освітній простір.

Адже освіта - це саме та сфера життєдіяльності цивілізованого суспільства, яка потребує постійного оновлення та змін.

Водночас очевидним $€$ те, що "розбудова будь-якої нової парадигми освіти", за словами Т. Степанової, "не можлива без її ретроспективного аналізу, без ґрунтовного вивчення досвіду попередніх поколінь щодо формування змісту освіти" (Степанова, 2011: 24).

Мета статті - здійснити узагальнений історико-педагогічний аналіз категорії “освіта”.

Методи та методики дослідження. У написанні статті було використано такі методи, як аналіз наукових джерел, систематизація та узагальнення даних з метою виявлення стану досліджуваної проблеми, метод наукової абстракції.

Результати та дискусії. Сьогодні існує багато точок зору дослідників на визначення поняття “освіта". Як соціальний і культурний феномен вона постійно привертає увагу з боку представників різних наук: філософії, психології, педагогіки, соціології, державного управління, які по-різному тлумачать це поняття. Цей факт можна пояснити тим, що саме в освітянській сфері віддзеркалюються суперечності суспільного розвитку, зокрема кризові явища, спричинені наслідками поступального руху цивілізації.

Поняття “освіта” з'явилося в науково-педагогічній літературі в кінці XVIII сторіччя як синонім до слова “виховання". Його почали використовувати для позначення формувального і виховного впливу навчання на особистість.

Ще Я. Коменський у своїх працях зазначав, що людині, якщо вона має бажання, прагнення стати Людиною, необхідно здобути освіту. На думку українського фрілософра Г. Сковороди (2011), люди повинні пізнавати себе, свої здібності і виробити відповідний своїй природі спосіб життя. Цьому сприяє освіта.

Український термін “освіта" відповідний німецькому "bildung”, a російському “образование” (утворення, створення образу) й розуміється як зміст і процес утворення, формування особистості за певним шаблоном, зразком. Такий саме зміст у поняття освіти вкладав Й. Песталоцці (1928), визначаючи їі як “формування образу”, усебічний розвиток людини. Відомий педагог чітко диференціював поняття "навчання" і “виховання”, розуміючи їх як шляхи здійснення освіти.

Починаючи 3 другої половини XIX століття поняття "освіта" отримало конкретний термінологічний зміст, його пов'язували 3 навчанням, що здійснює формувальний вплив на особистість.

У XX ст. у руслі радянської педагогіки в “основу семантичного поля цієї категорії було покладено процес оволодіння людиною знаннями, уміннями та навичками". Так, у радянському енциклопедичному словнику освіта визначалася як "результат засвоєння систематизованих знань, 
умінь, навичок; необхідна умова підготовки людини до життя та праці" (Ярошинська, 2014: 432).

Незважаючи на те, що існує багато різних точок зору на визначення поняття "освіта", в Україні легітимним $є$ те, яке зафіксовано в офріційних документах, а саме, в Законі "Про освіту": "Освіта є основою інтелектуального, духовного, фрізичного і культурного розвитку особистості, її успішної соціалізації, економічного добробуту, запорукою розвитку суспільства, об'єднаного спільними цінностями і культурою, та держави” (Закон України “Про освіту”, 2017: 1).

Інший офріційний документ - "Енциклопедія освіти" характеризує освіту як "спеціальну сфреру соціального життя, унікальну систему, своєрідний соціокультурний феномен, який сприяє нагромадженню знань, умінь і навичок, інтелектуальному розвитку людини" (Гончаренко, 2008: 614).

У контексті фрілософфії освіта розуміється не як цілеспрямований процес передачі готових знань та досвіду шляхом навчання і виховання, а процес розвитку та саморозвитку людини. Виступаючи для окремого індивіда і для усього суспільства найвищою духовною цінністю, освіта обумовлює їх становлення і розвиток. 3 цієї позиції суть освіти розуміється як одна із умов перетворення людини в духовне творіння, яке через зміст освіти змінює засіб бачення дійсності та розвивається як соціальний суб'єкт людської діяльності (Павицька, 2008).

$€$. Бондаревська (1999) зазначає, що освіта - це, перш за все, становлення людини, набуття нею себе, свого образу: індивідуальності, неповторності, духовності, творчого початку. Надати освіту людині означає не лише забезпечити засвоєння нею певної суми знань, а допомогти їй стати суб'єктом культури, який має свій власний інтерсуб'єктивний світ і є активним творцем свого життя.

Подібної думки дотримується й В. Краєвський, який, зазначає, що освіта $\epsilon$ "процесом залучення людини до культури і водночас результатом інтеріоризації культури, включенням ії у світ людської суб'єктивності як цілеспрямований процес виховання i навчання в інтересах людини, суспільства, держави: саме в такій послідовності пріоритетів за сучасних умов" (Краєвський, 2007: 132).

Освіту як відкриту синергетичну систему пропонує розглядати С. Сисоєва. 3 цієї позиції дослідниця трактує сферу сучасної освіти "як взаємодію складних підсистем, здатних до самоорганізації, саморозвитку і самоуправління, і як засіб, що забезпечує інтеграцію різних способів пізнання людиною навколишнього світу, підвищує творчий потенціал людини для вільних і осмислених дій, відкритого сприйняття й цілісного усвідомлення світу" (Сисоєва, 2012: 23).

Визначення освіти як педагогічної категорії трактується вченими як суспільно організований і внормований процес, спрямований на трансляцію соціально значущого та культурно-історичного досвіду від попередніх поколінь наступним (Лєдньов); як процес і результат оволодіння індивідом певної системи наукових знань, умінь та навичок і 
пов'язаний з ними рівень розвитку його розумової, пізнавальної та творчої діяльності, а також світогляду і моральності, які в сукупності визначають соціальний стан людини та її індивідуальність (Гончаренко, 2008); як особливий вид цілеспрямованої діяльності з метою підготовки людини до життя в суспільстві, яка складається з виховання та навчання та здійснюється в інтересах людини, суспільства й держави (Краєвський, 2007); як цілісний процес фрізичного та духовного формування особистості, соціалізації, свідомо орієнтований на певні ідеальні образи, на історично обумовлені, більш-менш чітко зафіксовані в суспільній свідомості соціальні еталони (Сластьонін, 2002).

Аналіз наукових розвідок щодо проблеми вказує на багатоаспектність як визначень поняття “освіта”, так і підходів щодо його вивчення, які можна систематизувати таким чином (див. рис.1.1).

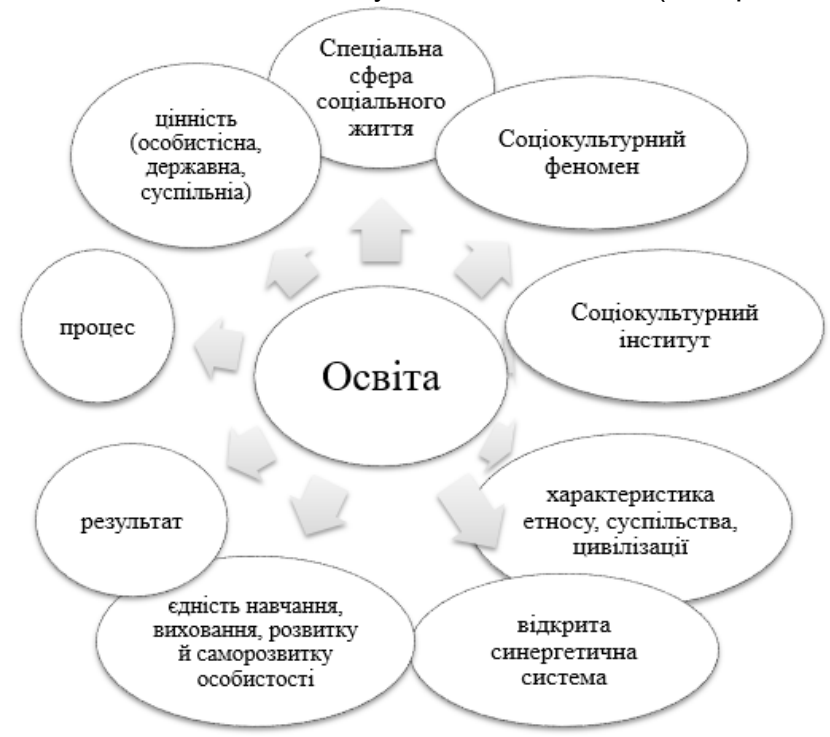

Рис.1.1. Сучасні підходи до розуміння освіти

Усю багатоаспектність трактування категорії "освіта" Б. Гершунський (1998) пропонує узагальнити, виокремивши чотири аспекти її змістового тлумачення: освіта як цінність (особистісна, суспільна, державна); освіта як система (різноманітних загальноосвітніх (державних і недержавних) закладів і освітніх установ; освіта як процес (цілісна єдність навчання, виховання, розвитку, саморозвитку особистості); освіта як різнорівневий результат .

3 цього приводу В. Кремень зазначає: "Освіта у XXI столітті - це не лише надання знань і виховання особистості. Освіта в добу глобалізації та високих технологій - це чинник соціальної стабільності, економічного 
добробуту країни, її конкурентоспроможності й національної безпеки. Тому освіту не можна й надалі стереотипно зараховувати до сфрери відомчої чи галузевої політики, а варто підходити до неї як до загальнонаціональної, стратегічно важливої проблеми" (Кремень, 2005: 395).

Функції освіти з різних позицій розглядали такі українські вчені, як В. Андрущенко, Ю. Зіньковський, В. Кремінь, З. Курлянд, Г. Семенова, В. Огневюк та ін.

На думку метра педагогіки С. Гончаренка, серед функцій освіти можна виділити такі основні: “людинотворчу - забезпечення певного рівня знань, грамотності; стану емоційно-вольової сфери, поведінкових орієнтацій, готовності до виконання різних соціальних ролей, видів діяльності тощо; технологічну - забезпечення «бази життя»; формування навичок і вмінь трудової, громадської, господарської, професійної діяльності; гуманістичну - виховання людей у дусі миру, високої моральності, культури, розуміння пріоритетів загальнолюдських цінностей (життя, праці, самої людини, природи тощо)" (Гончаренко, 2008: 615).

За словами Б. Гершунського (1998), освіта як процес за своєю сутністю - це рух до певної мети. Мета освіти розуміється як передача наступному поколінню культури у вигляді соціального досвіду, який містить в собі знання, уміння, навички, способи різних видів діяльності, цінності-відносини, які у своїй єдності забезпечують різноплановий розвиток особистості та ії спрямованість.

Тоді основними результатами цього руху, а отже, результативними компонентами освіти, виступають: грамотність; освіченість; професійна компетентність; культура; менталітет (Гершунський, 1998: 132]. Шлях від грамотності до менталітету - це процес руху особистості від освітнього мінімуму до найбільш високих освітніх результатів.

Висновки. Отже, історико-педагогічний аналіз дефрініції «освіта» виявив, що це поняття за роки свого існування суттєво змінило свій зміст і на сучасному етапі трактується дуже широко як у суспільному, так й у соціальному контексті. Прогрес людства, розвиток суспільства, національна безпека держав сьогодні обумовлюються саме розвитком освітньої сфери. Людські ресурси, особистісний капітал стають тим важелем, тим виміром, від якого залежить конкурентоспроможність будьякої держави. Цей фракт спонукає дослідників шукати нові шляхи розвитку освіти та оновлення ії̈ змісту.

\section{Література}

1.Бондаревская Е. Педагогическая личность в гуманистических теориях и системах воспитания / Е. Бондаревская, С. Кульневич. - Ростов-на-Дону: Творческий центр «Учитель», 1999. - С. 36.

2.Гершунский Б. Философия образования для XXI века (B поисках $\begin{array}{llll}\text { практикоориентированых концепций / } & \text { Б. Гершунский. - М.: Изд-во }\end{array}$ «Совершенство», 1998. - 608 с.

3.Енциклопедія освіти / Акад. пед. наук України; головний ред. В. Кремень. - К.: Хрінком Інтер, 2008. - 1040 с.

4.Краевский В. Основы обучения. Дидактика и методика: учебн. пособие 
для студентов высших учебных заведений / В. Краевский, А. Хуторской. - М.: Академия, 2007. - 352 с.

5. Кремень В. Освіта і наука в Україні - інноваційні аспекти / В. Кремень. К.: Грамота, 2005. - 448 с.

6.Огнев'юк В. Освіта в системі цінностей сталого людського розвитку : монографія / В. Огнев'юк. - К.: Знання України, 2003. - 448 с.

7.Павицька С. Освіта в контексті формування віртуальної культури особистості: Електронний ресурс / С. Павицька // Режим доступу: www.zgia.zp.ua/gazeta/VISNIK_35_21.pdf.

8.Песталоцці Й. Вибрані твори / [за ред. М. Гордієвського, А. ГоталоваГотріба і В. Чудновцева]. - Одеса, 1928. - 438 с.

9.Пидкасистый П. Педагогика : учебное пособие для вузов / П. Пидкасистый. - 2-е изд. - Москва : Издательство Юрайт, 2011. - 502 с.

10. Про освіту : Закон України № 2145-VIII від 05 вересня 2017 року [Електронний ресурс] // Офіційний веб-сайт Верховної ради України. Режим доступу : https://zakon.rada.gov.ua/laws/show/2145-19.

11. Сисоєва С. Сфера освіти як об'єкт дослідження / С. Сисоєва // Освітологія. - 2012. - Вип.1. - С. 22-29.

12. Сковорода Г. Повне зібрання творів у 2-х т. - Т. 1. Трактати та діалоги. - К.: Богуславкнига, 2011. - 432 с.

13. Сластенин В. Педагогика: учеб. пособие для студ. высш. пед. учеб. заведений / В. А. Сластенин, И. Ф. Исаев, Е. Н. Шиянов; [под ред. В.А. Сластенина]. - М.: Академия, 2002. - 576 с.

14. Степанова Т. Трансформації змісту передшкільної освіти в історії розвитку вітчизняної дошкільної педагогіки: методологія, теорія, практика (кінець XIX - XX ст.) [Текст] : дис. ... д-ра пед. наук : 13.00.01 : 13.00 .08 / Тетяна Степанова; Південноукр. нац. пед. ун-т ім. К. Д. Ушинського. - Одеса, 2011. - 595 c.

15. Уваркіна О. Українська освіта на шляху до єдиного європейського освітнього простору / О. Уваркіна // Вища освіта України. - 2012. - № 3. - С. 38-44.

16. Яровенко Т. Тенденції та проблеми розвитку освіти в Україні / Т. Яровенко // Економічний вісник Національного технічного університету України «Київський політехнічний інститут». - 2015. - № 12. - С. 167-172.

17. Ярошинська О. Освіта як невід'ємний конструкт поняття «освітнє середовище професійної підготовки майбутніх учителів початкових класів» / О. Ярошинська // Педагогічні науки: теорія, історія, інноваційні технології. - 2014. № 3 (37). - C. 430-441.

\section{References}

1.Bondarevskaya, E., Kulnevych, S. (1999). Pedagogicheskaya lichnost v gumanisticheskih teoriyah i sistemah vospitaniya [Pedagogical personality in humanistic theories and education systems]. Rostov-na-Donu: Tvorcheskyj centr «Uchytel» [in Russian].

2.Gershunskyj, B. (1998). Filosofiya obrazovaniya dlya XXI veka (V poiskah praktikoorientirovanyh koncepcij [Education Philosophy for the 21st Century (In Search of Practical Concepts]. Moskva: Sovershenstvo [in Russian].

3. Kremen, V. (Ed.). (2008). Encyklopediya osvity [Encyclopedia of Education]. Kyiv: Xrinkom Inter [in Ukrainian].

4.Kraevskij, V., Hutorskoj, A. (2007). Osnovy obucheniya. Didaktika i metodika: uchebn. posobie dlya studentov vysshih uchebnyh zavedenij [The basics of learning. Didactics and methodology: a textbook for students of higher educational institutions]. Moskva: Akademiya [in Russian].

5. Kremen, V. (2005). Osvita i nauka v Ukrayini - innovacijni aspekty [Education 
and Science in Ukraine are innovative aspects]. Kyiv: Gramota [in Ukrainian].

6. Ognevyuk, V. (2003). Osvita v systemi cinnostej stalogo lyudskogo rozvytku : monografiya [Education in the system of values of sustainable human development]. Kyiv: Znannya Ukrayiny [in Ukrainian].

7.Pavyczka, S. (2008). Osvita v konteksti formuvannya virtualnoyi kultury osobystosti [Education in the context of forming a virtual personality culture]. Retrieved from www.zgia.zp.ua/gazeta/VISNIK 35 21.pdf.

8. Pestaloczci, J. (1928). Vybrani tvory [Selected works]. Odesa [in Ukrainian].

9.Pidkasistyj, P. (2011). Pedagogika : uchebnoe posobie dlya vuzov [Pedagogy: study guide for universities]. Moskva: Yurajt [in Russian].

10. Pro osvitu : Zakon Ukrayiny № 2145-VIII vid 05 veresnya 2017 roku [On Education: Law of Ukraine No. 2145-VIII of September 05, 2017]. Retrieved from https://zakon.rada.gov.ua/laws/show/2145-19 [in Ukrainian].

11. Sysoyeva, S. (2012). Sfera osvity yak obyekt doslidzhennya [Education as a research object]. Osvitologiya, 1, 22-29 [in Ukrainian].

12. Skovoroda, G. (2011). Traktaty ta dialogy [Treatises and dialogues]. Povne zibrannya tvoriv (Vol. 1, 432 p.). Kyiv: Boguslavknyga [in Ukrainian].

13. Slastenin, V., Isaev, Y., Shiyanov, E. (2002). Pedagogika: ucheb. posobie dlya stud. vyssh. ped. ucheb. Zavedenij [Pedagogy: study guide for universities]. Moskva: Akademiya [in Russian].

14. Stepanova, T. (2011). Transformaciyi zmistu peredshkilnoyi osvity v istoriyi rozvytku vitchyznyanoyi doshkilnoyi pedagogiky: metodologiya, teoriya, praktyka (kinecz XIX - XX st.) [Transformations of content of preschool education in the history of development of domestic preschool pedagogy: methodology, theory, practice (end of $X I X$ - XX centuries)]. (Dys. d-ra ped. nauk). Pivdennoukrayinskyj nacionalnyj pedagogichnyj universytet im. K. D. Ushynskogo, Odesa [in Ukrainian].

15. Uvarkina, O. (2012). Ukrayinska osvita na shlyaxu do yedynogo yevropejskogo osvitnogo prostoru [Ukrainian education on the way to a single European educational space]. Vyshha osvita Ukrayiny, 3, 38-44 [in Ukrainian].

16. Yarovenko, T. (2015). Tendenciyi ta problemy rozvytku osvity v Ukrayini [Tendencies and problems of development of education in Ukraine]. Ekonomichnyj visnyk Nacionalnogo texnichnogo universytetu Ukrayiny «Kyyivskyj politexnichnyj instytut», 12, 167-172 [in Ukrainian].

17. Yaroshynska, O. (2014). Osvita yak nevidyemnyj konstrukt ponyattya «osvitnye seredovyshhe profesijnoyi pidgotovky majbutnix uchyteliv pochatkovyx klasiv» [Education as an integral construct of the concept of "educational environment for the professional training of future primary school teachers"]. Pedagogichni nauky: teoriya, istoriya, innovacijni texnologiyi, 3 (37), 430-441 [in Ukrainian].

\section{АНОТАЦІЯ}

У статті поданий ретроспективний аналіз поняття "освіта", що з'явилося в науково-педагогічній літературі в кінці вісімнадиятого сторіччя як синонім до слова "виховання" і поступово набувало все ширшого контексту. У написанні статmі було використано такі методи, як аналіз наукових джерел, систематизація та узагальнення даних з метою виявлення стану досліджуваної проблеми, метод наукової абстракції.

За допомогою вищеназваних методів визначено, що динаміка змін у трактуванні дефініції "освіта", урізноманітнення його контексту обумовлено підвищенням ролі освітньої сфери для життєдіяльності та розвитку сучасного суспільства. Сьогодні існують різні підходи до трактування цього поняття, які розглянуто та узагальнено в статmі: освіта як характеристика етносу, цивілізації, суспільства; освіта як соціокультурний феномен, спеціальна сфера 
соціального життя; освіта як цінність (особистісна, суспільна, державна); освіта як система (різноманітних загальноосвітніх (державних і недержавних) закладів і освітніх установ); освіта як процес (цілісна єдність навчання, виховання, розвитку, саморозвитку особистості); освіта як різнорівневий результат.

Проаналізовано характеристики, ознаки та тенденції розвитку освіти на сучасному етапі. Прогрес людства, розвиток суспільства, національна безпека держав сьогодні обумовлюються саме розвитком освітньої сфери. Людські ресурси, особистісний капітал стають тим важелем, тим виміром, від якого залежить конкурентоспроможність будь-якої держави.

Розкрито функції освіти, серед яких можна виділити основні: людинотворчу - сприяння утворенню певного рівня знань, грамотності, освіченості; технологічну - формування навичок $і$ вмінь у різних видах діяльності; гуманістичну - фрормування у зростаючої особистості високої моральності, культури, духовних цінностей. Визначено результативні компоненти освіти: грамотність; освіченість; професійна компетентність; культура; менталітет. Шлях у напрямку від грамотності до менталітету - це процес руху особистості від освітнього мінімуму до найбільш високих освітніх результатів.

Ключові слова: освіта, система освіти, навчання, виховання, цінність, культура, освіченість. 